\title{
PENGARUH PEMBERIAN PAKAN AMPAS TAHU DAN DAUN Indigofera zollingeriana Miq. TERHADAP PERTUMBUHAN AYAM KAMPUNG (Gallus-gallus domesticus L. variasi joper) SEBAGAI SUMBER BELAJAR BIOLOGI
}

\author{
Eka Zulfitri ${ }^{1}$ \\ Suharno Zen ${ }^{2}$ \\ Rasuane Noor ${ }^{3}$ \\ 1, 2, 3, Pendidikan Biologi Universitas Muhammadiyah Metro \\ E-mail:1ekazulfitri47@gmail.com,2suharnozein@gmail.com,3rasuanenoor@gmail.com
}

\begin{abstract}
The aim of this research was 1) to determine the effect of giving a combination of tofu pulp and indigofera leaves to the growth of super native chicken, 2) to determine the concentration of a combination of tofu pulp and indigofera leaves which is good for the growth of super native chicken, 3) to determine the utilization of learning outcomes as a learning resource in the form of a poster. This type of research is experimental research with a completely randomized design (CRD). This study used a total sample of 24 stater phase chicken (aged 20 days after hatching). This study used 4 treatments, namely the combination of tofu dregs feed and indigofera leaves with a concentration of $17 \%$ indigofera leaves mixed $83 \%$ tofu dregs, $35 \%$ concentration of indigofera leaves mixed $65 \%$ tofu dregs, and $70 \%$ concentration of indigofera leaves mixed $30 \%$ tofu dregs, and a control treatment with centrate feed. Each treatment was given $6 x$ repetitions. The parameters observed in this study were weight, and diameter of super native chicken. Data were analyzed using a one-way Non-parametric Test called the Kruskal Wallis Test. Based on the results of the study, there was a significant influence on the feeding of tofu pulp and indigofera leaves to the growth of super native chicken. The results of the study are based on the analysis of the Kruskal Wallis test $x 2$ hit> x2daf. Further tests showed the best concentration of tofu pulp and indigofera leaves for super native chicken growth was a concentration of $17 \%$ indigofera leaves $+83 \%$ tofu pulp. Based on the analysis of the validation of learning resources, this study deserves to be used as a source of learning biology in the form of posters for the growth and development of class XII.
\end{abstract}

Kata kunci: super java chicken, Indigofera, alternative feed, poster learning resources

\section{PENDAHULUAN}

Peningkatan jumlah populasi dan tingkat produksi ayam kampung (Gallusgallus domesticus L. variasi joper) perlu diimbangi dengan peningkatan ketersediaan pakan. Untuk pertumbuhan yang cepat dan produktivitas tinggi diperlukan pakan yang cukup mengandung zat makanan yang dibutuhkan, baik secara kualitas maupun kuantitas. Menekan biaya produksi sekecil mungkin tanpa mengurangi produksi optimum dapat dilakukan dengan cara memanfaatkan bahan pakan alternatif.

Pakan merupakan unsur utama dari faktor penentu keberhasilan dalam usaha peternakan. Penggunaan bahan pakan alternatif atau bahan pakan non konvensional sangat dibutuhkan dan perlu diupayakan untuk menekan biaya produksi. Dengan adanya penggunaan pakan secara alternatif sebagai sumber pakan yang harus disesuaikan dengan kebutuhan nutrisi ternak agar mendapatkan hasil yang optimal (Allama $\mathrm{dkk}$, 2018). Pemberian ransum bertujuan 
untuk menjamin pertumbuhan berat badan, produksi telur, dan daging agar menguntungkan. Tujuan tersebut dapat tercapai apabila memahami prinsip dasar tentang ransum. Zat yang dibutuhkan untuk pertumbuhan ayam berupa air, protein, lemak, karbohidrat, mineral, asam amino dan vitamin (Sudaro \& Anita, 2007).

Penggunaan ampas tahu sebagai pakan ikan patin menunjukkan hasil terbaik dari kombinasi ampas tahu 75\% dan tepung tapioka $25 \%$ dapat meningkatkan protein sebesar $129,58 \%$. Hal tersebuat dapat dilihat bahwa ampas tahu yang hanya terbuat dari limbah ternyata memiliki kandungan yang baik untuk pakan alternatif hewan ternak (Melati dkk, 2010).

$$
\text { Indigofera (Indigofera }
$$

zollingeriana Miq.) termasuk ke dalam tanaman leguminosa pohon tropis dan memiliki kandungan nutrisi yang baik untuk hewan ternak ruminansia. Selain hewan ternak ruminansia tanaman indigofera (Indigofera zollingeriana Miq.) juga dapat dijadikan bakan pakan bagi hewan ternak lainnya. Karena dalam tanaman indigofera memiliki kandungan protein kasar yang tergolong cukup tinggi berkisar antara 22-29\% sedangkan kandungan serat (NDF) tergolong rendah yaitu antara 22-46\% sehingga bagus untuk bahan pakan hewan ternak (Tarigan \& Ginting, 2011).

Ayam kampung (Gallus-gallus domesticus L. variasi joper) mempunyai pertumbuhan yang lebih cepat daripada ayam kampung lokal (Gallus-gallus domesticus L.), karena ayam kampung (Gallus-gallus domesticus L.) disilangkan dengan ayam ras akan menghasilkan ayam joper. Ayam kampung (Gallus-gallus domesticus L. variasi joper) super dari 100 ekor DOC (37 g/ekor) sampai masa panen (60 hari) dengan berat $0,9 \mathrm{kh} / \mathrm{ekor}$ (Trisiwi, 2016).

Berdasarkan pendahuluan tersebut maka akan dilakukan penelitian pemberian pakan ampas tahu dan daun indigofera (Indigofera zollingeriana Miq.) terhadap pertumbuhan ayam kampung (Gallus-gallus domesticus L. variasi joper), diharapkan pakan tersebut dapat meningkatkan pertumbuhan ayam kampung (Gallus-gallus domesticus L.variasi joper). Hasil penelitian ini nantinya akan dimanfaatkan untuk proses belajar mengajar pada mata pelajaran biologi dalam bentuk poster.

$\begin{array}{rrr}\text { Media } & \text { poster } & \text { merupakan } \\ \text { penjelasan } & \text { mengenai } & \text { pergeseran } \\ \text { kesetimbangan } & \text { akibat } & \text { perubahan }\end{array}$ kosentrasi disertai contoh. Sumber belajar berupa poster berisikan latar belakang, tujuan, metode penelitian, data hasil pengamatan, kesimpulan, saran, daftar pustaka, dan lampiran yang dirancang dengan singkat agar memudahkan untuk para pembaca (Umami dkk, 2016).

\section{METODE}

Penelitian ini dilakukan di Desa Sumber Baru Seputih Banyak. Jenis penelitian ini adalah penelitian eksperimen kuantitatif dengan menggunakan Rancangan Acak Lengkap (RAL). Subjek dalam penelitian ini adalah pertumbuhan ayam kampung (Gallus-gallus domesticus L. variasi joper). Parameter yang diamati dalam penelitiaan ini adalah berat dan diameter perut bagian badan. Sampel yang digunakan dalam penelitian ini adalah 1 kontrol 3 perlakuan. Setiap perlakuan terdapat 6 kali ulangan dan setiap ulangan 
terdapat 1 ekor ayam joper. Sampel digunakan yaitu 24 ekor ayam kampung (Gallus-gallus domesticus L. variasi joper). P0: kontrol, P1: pemberian kombinasi pakan $17 \%$ indigofera $+83 \%$ ampas tahu, P2: pemberian kombinasi pakan $35 \%$ indigofera $+65 \%$ ampas tahu, P3: pemberian kombinasi pakan $70 \%$ indigofera $+30 \%$ ampas tahu.

Bahan yang digunakan pada penelitian ini adalah ampas tahu sisa dari limbah pembuatan tahu, daun indigofera (Indigofera zollingeriana Miq.) yang sudah tua, anakan ayam kampung (Gallus-gallus domesticus L. variasi joper) yang berumur 20 hari. Menyiapkan kandang yang terbuat dari kayu pada sisi samping, atas dan bawah dengan panjang dan lebar $300 \mathrm{~cm} \mathrm{x} 70 \mathrm{~cm}$ yang akan dibagi 4 petak tiap petak akan diisi 6 ekor anakan ayam kampung (Gallus-gallus domesticus L. variasi joper).

Cara pembuatan pakan yaitu ampas tahu yang terbuat dari limbah pembuatan tahu dijemur sampai keadaan benar-benar kering. Daun indigofera (Indigofera zollingeriana Miq.) yang tua dijemur sampai kering kemudian diblender sampai tekstur benar-benar halus. Ampas tahu yang sudah kering kemudian dicampurkan dengan daun indigofera (Indigofera zollingeriana Miq.) yang sudah halus.

Data dianalisis menggunakan Uji Kruskal Wallis. Berdasarkan hasil penelitian, terdapat pengaruh nyata pemberikan pakan ampas tahu dan daun indigofera (Indigofera zollingeriana Miq.) terhadap prtumbuhan ayam kampung (Gallus-gallus domesticus L. variasi joper). Hasil penelitian berdasarkan analisis uji kruskal wallis ?X^2?_hitung>? $\mathrm{X}^{\wedge} 2$ ?_( daftar). Uji lanjut menunjukkan konsentrasi pakan ampas tahu dan daun indigofera yang paling baik untuk pertumbuhan ayam kampung (Gallus-gallus domesticus L. variasi joper) adalalah konsentrasi $17 \%$ daun indigofera $+83 \%$ ampas tahu.

\section{HASIL}

Tabel 1. Pertumbuhan Rata-Rata Keseluruhan Berat (gram) Ayam Kampung (Gallus-gallus domesticus L. variasi joper) Pada 4 Perlakuan

\begin{tabular}{|c|c|c|c|c|}
\hline \multirow{2}{*}{ Ulangan } & \multicolumn{4}{|c|}{ Perlakuan } \\
\cline { 2 - 5 } & P0 & P1 & P2 & P3 \\
\hline 1 & 167,2 & 196,2 & 187,8 & 158 \\
\hline 2 & 155,8 & 194,6 & 229,4 & 201,4 \\
\hline 3 & 166 & 219,6 & 227,2 & 147,8 \\
\hline 4 & 176,2 & 187,8 & 166,6 & 146,2 \\
\hline 5 & 187,2 & 236 & 203,4 & 141,6 \\
\hline 6 & 196,6 & 242 & 201,6 & 160,4 \\
\hline$X$ & 174,8 & 212,7 & 202,7 & 159,2 \\
\hline
\end{tabular}

Keterangan:

$\mathrm{P} 0=$ Perlakuan kontrol dengan pemberian pakan sehari-hari berupa sentrat (tanpa pemberian perlakuan)

P1= Perlakuan 1 dengan pemberian kombinasi pakan 17 gram indigofera dan 83 ampas tahu

P2 = Perlakuan 2 dengan pemberian kombinasi pakan 35 gram indigofera dan 65 ampas tahu

P3= Perlakuan 3 dengan pemberian kombinasi pakan 70 gram indigofera dan 30 ampas tahu

Tabel 2. Pertumbuhan Rata-Rata Keseluruhan Diameter (cm) Ayam Kampung (Gallus-gallus domesticus L. variasi joper) Pada 4 Perlakuan

\begin{tabular}{|c|l|l|l|l|}
\hline \multirow{2}{*}{ Ulangan } & \multicolumn{4}{|c|}{ Perlakuan } \\
\cline { 2 - 5 } & P0 & P1 & P2 & P3 \\
\hline 1 & 19,4 & 20,4 & 20,8 & 19 \\
\hline
\end{tabular}




\begin{tabular}{|c|c|c|c|c|}
\hline 2 & 19 & 20,6 & 21,8 & 20,4 \\
\hline 3 & 19,6 & 21,4 & 21,6 & 19 \\
\hline 4 & 20 & 20,4 & 19,4 & 19 \\
\hline 5 & 20,2 & 21,6 & 21 & 19 \\
\hline 6 & 20,6 & 21,6 & 21 & 19 \\
\hline$X$ & 19,8 & 21 & 20,9 & 19,2 \\
\hline Keterangan:
\end{tabular}

$\mathrm{P} 0=$ Perlakuan kontrol dengan pemberian pakan sehari-hari berupa sentrat (tanpa pemberian perlakuan)

$\mathrm{P} 1=$ Perlakuan 1 dengan pemberian kombinasi pakan 17 gram indigofera dan 83 ampas tahu

P2= Perlakuan 2 dengan pemberian kombinasi pakan 35 gram indigofera dan 65 ampas tahu

P3= Perlakuan 3 dengan pemberian kombinasi pakan 70 gram indigofera dan 30 ampas tahu

\section{PEMBAHASAN}

Pemberian pakan pada ayam kampung (Gallus-gallus domesticus L. variasi joper) memiliki pengaruh terhadap pertumbuhan berat ayam kampung (Gallus-gallus domesticus L. variasi joper). Pertumbuhan rata-rata keseluruhan berat ayam kampung (Gallus-gallus domesticus L. variasi joper) pada 4 perlakuan, Pada perlakuan diberi pakan kombinasi 17 gram indigofera +83 gram ampas tahu memiliki hasil yang optimum dengan rata-rata keseluruhan 212,7 gram. Pada perlakukan yang diberi pakan kombinasi 35 gram indigofera +65 gram ampas tahu memiliki hasil optimum yang kedua dengan rata-rata keseluruhan 202,7 gram. Pada perlakuan yang diberi pakan kombinasi 70 gram indigofera +30 gram ampas tahu memiliki hasil yang paling rendah dengan rata-rata keseluruhan 159,2 gram. pada kontrol berupa pakan sehari-hari atau sentrat memiliki hasil yang kurang optimum dengan rata-rata keseluruhan 174,8 gram.
Pada kontrol dengan pemberian pakan sehari-hari berupa sentrat mnenunjukkan berat yang kurang optimum. Cahaya merupakan faktor lingkungan yang sangat penting dalam proses berlangsungnya kehidupan ayam kampung (Gallus-gallus domesticus L. variasi joper), karena cahaya mengontrol banyak proses fisiologi dan tingkah laku ayam, mengontrol pertumbuhan, meningkatkan efisien pakan, meminimalkan mortalitas, mengurangi problem kaki, mengurangi mati mendadak, meningkatkan kemampuan hidup (Setianto, 2009).

Faktor selanjutnya yaitu suhu, suhu merupakan gabungan panas lingkungan berasal dari radiasi matahari dan panas metabolisme dalam tubuh ayam yang dilepaskan ke lingkungan. Suhu berpengaruh langsung terhadap kenyamanan, karena suhu kandang mengikuti suhu lingkungan. Kenaikan suhu lingkungan sangat mempengaruhi produksi ayam pedaging. Salah satu faktor yang mempengaruhi kelembaban udara adalah suhu. Kelembaban berkaitan dengan suhu udara, semakin tinggi suhu udara maka kelembaban akan semakin rendah. Suhu dan kelembaban yang tinggi dapat menjadi penyebab utama stres pada hewan ternak terutama unggas. Kanikan suhu dan kelembaban kandang disebabkan oleh lingkungan, letak kandang atau posisi kandang (Qurniawan dkk, 2016).

Pada perlakuan dengan pemberian kombinasi pakan 17 gram indigofera +83 gram ampas tahu merupakan berat tertinggi sebesar 212,7 gram dan P2 dengan pemberian kombinasi pakan 35 gram indigofera +65 ampas tahu sebesar 20,9 gram. 
Kandungan pada ampas tahu memiliki protein 23\%, karbohidrat 26,92\%, lemak 5,54\%, serat kasar $16,53 \%$, abu $17,03 \%$, air $10,43 \%$ sehingga baik untuk membantu pertumbuhan ayam kampung (Gallusgallus domesticus L. variasi joper). Hal tersebut diperkuat dengan pernyataan Tribina (2012). Semakin banyak ampas tahu yang digunakan semakin banyak protein, karbohidrat, dan lemak yang terdapat dalam pakan membuat ayam cepat tumbuh.

Karbohidrat selain berfungsi untuk menghasilkan energi mempunyai fungsi yang lain yaitu pemberi rasa manis pada pakan, penghemat protein, pengatur metabolisme lemak, membantu mengeluarkan fases, sehingga karbohidrat yang diberikan untuk pakan ayam kampung (Gallus-gallus domesticus L. variasi joper) yang sesuai akan menghasilkan energi dan membuat ayam tumbuh dengan optimal (Siregar, 2014). Kandungan lemak yang tinggi dapat menyebabkan konsumsi lemak didalam tubuh ayam kampung (Gallusgallus domesticus L. variasi joper) menjadi tinggi. Konsumsi lemak yang tinggi kemungkinan tidak diimbangi dengan banyaknya garam-garam empedu yang dihasilkan dari hati untuk mengabsorbsi lemak dalam saluran pencernaan (Kiha, \& Murningsih, 2012).

Garam-garam empedu merupakan garam-garam basa yang dapat membantu dalam menciptakan susunan yang alkalis dalam usus halus agar absorbsi berlangsung dengan lancar. Ketika nutrisi lemak yang terkandung dalam pakan tidak sesuai dengan kebutuhan pertumbuhan ayam kampung (Gallus- gallus domesticus L. variasi joper) tidak optimal (Widodo, 2000).

Pada perlakuan dengan pemberian kombinasi pakan 70 gram indigofera +30 gram ampas tahu merupakan Berat yang paling rendah sebesar 19,2 gram. Kandungan protein kasar beberapa spesies Indigofera sp tergolong tinggi berkisaran 22-29\% sedangkan kandungan serat (NDF) tergolong rendah yaitu 22$46 \%$. Hal tersebut diperkuat dengan pernyataan Tarigan \& Ginting (2011) sehingga kurang baik jika digunakan terlalu berlebihan karena memiliki kandungan serat kasar yang tinggi.

Serat kasar berfungsi sebagai penahan lapar sehingga ayam kampung (Gallus-gallus domesticus L. variasi joper) mengurangi aktivitas untuk mengkonsumsi pakan. Serat kasar yang tinggi mempengaruhi daya cerna ayam kampung (Gallus-gallus domesticus L. variasi joper). Penurunan bobot ayam kampung (Gallus-gallus domesticus L. variasi joper) disebabkan kandungan serat kasar yang tinggi sehingga serat makanan setelah dalam saluran pencernaan akan mengikat asam empedu. Asam empedu sebelum membantu dalam proses penyerapan lemak akan dikeluarkan dari dalam tubuh berbentuk fases sehingga menyebabkan kontraksi di usus halus semakin cepat, dan menyebabkan substrat makanan yang diserap akan sedikit membuat bobot ayam kampung (Gallusgallus domesticus L. variasi joper) (Erniasih \& Tyas, 2006).

Pertumbuhan diameter $(\mathrm{cm})$ ayam kampung (Gallus-gallus domesticus L. variasi joper) dengan perlakuan P0, P1, P2, P3. Pertumbuhan diameter dipengaruhi oleh nutrisi yang seimbang, nutrisi yang tidak seimbang 
mengakibatkan pertumbuhan yang terganggu. Pada P0 yang diberi pakan berupa sentrat memiliki diameter sebesar $19,8 \mathrm{~cm}$ tergolong memiliki pertumbuhan yang kurang optimal. Hal tersebut dipengaruhi oleh faktor lingkungan diantaranya adalah cahaya, suhu, dan kelembaban. Ketika nutrisi pada ayam kampung (Gallus-gallus domesticus L. variasi joper) terpenuhi tetapi faktor lingkungan tidak diperhatikan akan mengganggu pertumbuhan ayam kampung (Gallus-gallus domesticus L. variasi joper) sehingga tidak dapat tumbuh dengan optimal.

Perlakuan yang merupakan kombinasi pakan 17 gram indigofera +83 gram ampas tahu didapatkan hasil diameter sebesar 21 dan yang merupakan kombinasi pakan 35 gram indigofera +65 gram ampas tahu didapatkan hasil diameter mutlak sebesar 20,9 gram. Perlakuan P1 dan P2 memiliki nutrisi yang seimbang yaitu protein, karbohidrat, lemak. Kombinasi pakan yang digunakan terdapat protein, karbohidrat, lemak yang sesuai dengan kebutuhan ideal pertumbuhan ayam kampung (Gallusgallus domesticus L. variasi joper). Kandungan protein yang sesuai maka bobot dan diameter ayam kampung (Gallus-gallus domesticus L. variasi joper) dapat tumbuh dengan optimal. Dengan protein yang cukup maka pembentukkan enzim yang diperlukan untuk pembentukkan antibodi akan tercukupi, sehingga ayam kampung (Gallus-gallus domesticus L. variasi joper) yang proteinnya terpenuhi akan tahan terhadap penyakit.

Perlakuan kombinasi pakan 70 gram indigofera +30 gram ampas tahu daidapatkan hasil diameter sebesar 19,2 gram merupakan hasil terkecil dari yang lainnya. Kombinasi pakan yang digunakan memiliki serat kasar yang tinggi sehingga menghambat diameter ayam kampung (Gallus-gallus domesticus L. variasi joper) dan serat kasar yang tinggi akan mempengaruhi daya cerna ayam kampung (Gallus-gallus domesticus L. variasi joper).

Poster yang dibuat dalam penelitian adalah poster yang hanya sampai pada tahap pengembangan, kemudia dilakukan uji validasi oleh beberapa tim ahli oleh dosen Universitas Muhammadiah Metro antara lain: ahli kelayakan isi materi dan ahli kelayakan desain. Poster yang dibuat berisikan hasil penelitian pengaruh pemberian pakan ampas tahu dan daun indigofera (Indigofera zollingeriana Miq.) terhadap pertumbuhan ayam kampung (Gallusgallus domesticus L. variasi joper). Komponen poster yang berisikan latar belakang, tujuan, metode penelitian, data hasil pengamatan, kesimpulan, saran, daftar pustaka, dan lampiran yang dirancang dengan singkat agar memudahkan untuk para pembaca.

Berdasarkan analisis data sumber belajar berupa poster yang telah dikembangkan mendapatkan hasil validasi dosen ahli materi sebesar 93\%, yang artinya poster yang dikembangkan memiliki kualifikasi sangat baik sehingga poster dapat digunakan sebagai sumber belajar biologi. (Ramlan, 2013).

Berdasarkan analisis data sumber belajar berupa poster yang telah dikembangkan mendapatkan hasil validasi dosen ahli desain sebesar $86,6 \%$, yang artinya, poster yang dikembangkan memiliki kualifikasi sangat baik sehingga 
poster dapat digunakan sebagai sumber belajar biologi (Ramlan, 2013).

\section{KESIMPULAN}

Berdasarkan hasil penelitian yang telah dilakukan dapat disimpulkan bahwa: Terdapat pengaruh pemberian pakan ampas tahu dan daun indigofera (Indigofera zollingeriana Miq.) terhadap pertumbuhan ayam kampung (Gallusgallus domesticus L. variasi joper) yang dipengaruhi oleh faktor hormon, nutrisi, kelembaban, suhu, dan cahaya.

Terdapat perbedaan Terdapat pengaruh pemberian pakan ampas tahu dan daun indigofera (Indigofera zollingeriana Miq.) terhadap pertumbuhan ayam kampung (Gallusgallus domesticus L. variasi joper) yang meliputi berat dan diameter ayam kampung (Gallus-gallus domesticus L. variasi joper).

Poster yang dikembangkan telah melalui tahap validasi materi dan desain, berdasarkan analisis penilaian validasi yang dilakukan poster telah layak digunakan sebagai sumber belajar biologi.

\section{SARAN}

Penelitian selanjutnya dapat memilih kombinasi pakan alternatif yang memiliki nutrisi yang lebih baik agar mendapatkan hasil yang optimal dan lebih memperhatikan faktor lingkungan seperti cahaya, suhu, dan kelembaban karena dapat mempengaruhi pertumbuhan dan perkembangan ayam kampung (Gallus-gallus domesticus L. variasi joper).

Hasil penelitian pengaruh pemberian ampas tahu dan daun indigofera (Indigofera zollingeriana
Miq.) dapat digunakan sebagai sumber belajar biologi berupa poster pada materi pertumbuhan dan perkembangan kelas XII semoga bermanfaat sebagai referensi pembelajaran.

\section{DAFTAR RUJUKAN}

Allama, H., Sofyan, O., Widodo, E., \& Prayogi, H. S. 2018. Pengaruh Penggunaan Tepung Ulat Kandang (Alphitobius diaperinus) dalam Pakan terhadap Penampilan Produksi Ayam Pedaging. J.Ilmuilmu Peternakan, 22(3), 1-8.

Melati, I., Zafril, I.A., \& Titik. 2010. Pemanfaatan Ampas Tahu Terfermentasi sebagai Subtitusi Tepung Kedelai dalam Formulasi Pakan Ikan Patin. Prosiding Forum Inovasi Teknologi Akuakultur. Bogor: Balai Riset Perikanan Budidaya Air Tawar.

Erniasih, I., \& Tyas. R. S. 2006. Penambahan Limbah Padat Kunyit (Curcuma domestica) Pada Ransum Ayam dan Pengaruhnya terhadap Status Darah dan Hepar Ayam (Gallus sp). Jurnal Buletin Anatomi dan Fisiologi, 14(2), 1-6.

Kiha, A. F., \& Murningsih, T. 2012. Pengaruh Pemeraman Ransum dengan Sari Daun Pepaya terhadap Kecernaan Lemak dan Energi Metabolis Ayam Broiler. Jurnal Animal Agricultural, 1(1), 266274.

Qurniawan, A., Irma. I. A., \& Rudi. A. 2016. Performans Produksi Ayam Pedaging Pada Lingkungan Pemeliharaan dengan Ketinggian yang Berbeda di Sulawesi Tenggara. Jurnal Vateriner, 17 (4), 622-633. 
Ramlan, Haeruddin \& Jamaluddin. 2013. Pengembangan Media

Pembelajaran E-materi dengan Model Pembelajaran Berbasis Masalah pada materi suhu dan kalor. Jurnal Pendidikan Fisika Tadulako (IPFT), 1(2), h. 12-17.

Setianto, J. 2009. Program Pencahayaan Untuk Ayam Pedaging. Jurnal Sains Peternakan Indonesia, 3(1), 24-29.

Siregar, N. S. 2014. Karbohidrat. Jurnal Ilmu Keolahragaan, 13(2), 38-44.

Sudaro, Y., \& Anita, S. 2007. Ransum Ayam dan Itik. Jakarta: Penebar Swadaya.

Tarigan, A. \& S. P. Ginting. 2011. Pengaruh Taraf Pemberian Indigofera Sp Terhadap Konsumsi dan Kecernaan Pakan Serta Pertambahan Bobot Hidup Kambing yang Diberi Rumput Brachiaria Ruziziensis. JITV, 16 (1), 25-32.

Tribina, A. 2012. Pemanfaatan Silase Kering Ampas Tahu Untuk Pakan Ikan Nila Merah (Oreochromis Niloticus). Jurnal Teknologi Perikanan dan Kelautan, 3(1): 2733.

Trisiwi, H. F. 2016. Pengaruh Level Protein Pakan Yang Berbeda Pada Masa Starter Terhadap Penampilan Ayam Kampung Super. Jurnal Ilmiah Peternakan Terpadu, 4(3), 256-262.

Umami, M., Suryadi, B. U., \& Ashadi. 2016. Pengaruh Media Infografis Dan Poster Pada Pembelajaran Joyful Learning Terhadap Prestasi Belajar Siswa Ditinjau Dari Kemampuan Logika Pada Materi Pokok Kesetimbangan Kimia Kelas
Xi Ipa Semester Gasal Sma Negeri Gondangrejo Tahun Pelajaran 2015/2016. Jurnal Pendidikan Kimia (JPK), 5(3), 9-17.

Widodo, W. 2000. Nutrisi dan Pakan Unggas Kontekstual Cetakan Pertama. Yogyakarta: Kanisius. 